[16] Deviniak, O. T., Lesyk, R. B. (2013). Doslidzhennia zviazku mizh strukturoiu 4-tiazolidynoniv ta yikh protypukhlynnoiu aktyvnistiu za dopomohoiu bahatovymirnykh adaptyvnykh rehresiinykh splainiv. Zhurnal orhanichnoi ta farmatsevtychnoi khimii, 10 (4 (40)), 76-82.

[17] Turchyna, S. Y. (2013). Diffuznyy netoksicheskiy zob i polovoe sozrevanie. Ukrainskyi zhurnal dytiachoi endokrynolohii, 1, 23-28.

[18] Kravchun, N. A., Chernyavskaya, I. V. (2011). Gipotireoz: epidemiologiya, diagnostika, opyt lecheniya. Problemy endokrynnoi patolohii, 3, 27-34.

[19] Zimmermann, M. B., Molinari, L., Spehl, M., Weidinger-Toth, J., Podoba, J., Hess, S., Delange, F. (2001). Updated Provisional WHO/ICCIDD Reference Values for Sonographic Thyroid Volume in Iodine-Replete School-age Children. IDD Newsletter, 17 (1), 12.

[20] Shilin, D. Ye. (2002). Aktual'nyye voprosy laboratornoy diagnostiki zabolevaniy shchitovidnoy zhelezy (sovremennyye rekomendatsii mezhdunarodnykh organizatsiy. Laboratoriya, 3, 22-26.

[21] Zimmermann, M. B., Hess, S. Y., Molinari, L., de Benoist, B., Delange, F., Braverman, L. E. et. al. (2004). New reference values for thyroid volume by ultrasound in iodine-sufficient schoolchildren: a World Health Organization/Nutrition for Health and Development Iodine Deficiency Study Group Report. The American Journal of Clinical Nutrition, 79 (2), 231-237. doi: 10.1093/ajcn/79.2.231

\title{
RESEARCH OF CERTAIN PATHOGENIC CHARACTERISTICS OF CLINICAL ISOLATES OF STAPHYLOCOCCI OF SKIN BIOME
}

\author{
Yanina Kutasevych \\ Director \\ $S E$ «Institute of Dermatology and Venerology of National Academy of Medical Sciences of Ukraine» \\ 7/9 Chernyshevka str., Kharkiv, Ukraine, 61057 \\ Svetlana Dzhoraeva \\ Laboratory of Microbiological \\ $S E$ «Institute of Dermatology and Venerology of National Academy of Medical Sciences of Ukraine» \\ 7/9 Chernyshevka str., Kharkiv, Ukraine, 61057 \\ Valentina Goncharenko \\ Laboratory of Microbiological \\ $S E$ «Institute of Dermatology and Venerology of National Academy of Medical Sciences of Ukraine» \\ 7/9 Chernyshevka str., Kharkiv, Ukraine, 61057 \\ Yuliia Shcherbakova \\ $S E$ «Institute of Dermatology and Venerology of National Academy of Medical Sciences of Ukraine» \\ 7/9 Chernyshevka str., Kharkiv, Ukraine, 61057 \\ Viktoriya Mangusheva \\ Department of dermatology, infectious and parasitical of skin disease \\ $S E$ «Institute of Dermatology and Venerology of National Academy of Medical Sciences of Ukraine» \\ 7/9 Chernyshevka str., Kharkiv, Ukraine, 61057

\section{Nataliya Sobol \\ Laboratory of Clinical} \\ $S E$ «Institute of Dermatology and Venerology of National Academy of Medical Sciences of Ukraine» \\ 7/9 Chernyshevka str., Kharkiv, Ukraine, 61057
}




\author{
Helen Shchegoleva \\ Laboratory of Microbiological \\ SE «Institute of Dermatology and Venerology of National Academy of Medical Sciences of Ukraine» \\ 7/9 Chernyshevka str., Kharkiv, Ukraine, 61057
}

\begin{abstract}
A serious problem in patients with atopic dermatitis (AD) is the frequent attachment of a secondary skin infection. Among the microbes colonizing the skin of patients suffering from AD, S. aureus takes the lead. According to different authors, from the skin of $80-95 \%$ of patients are sown Staphylococcus aureus. The survival of bacteria in a biotope is promoted by the persistent properties of microorganisms.

Aim of the research: to determine the adhesive properties and antilysozyme activity of clinical strains of staphylococci isolated from the skin of patients with allergic dermatosis.

The study included 50 patients with atopic dermatitis and 20 practically healthy individuals, from which 140 laboratory strains of staphylococci were isolated: 101 strains from patients with AD and 39 control strains. Bacteriological studies to isolate microorganisms and determine a number of pathogenic characteristics were carried out using the methods of classical bacteriology.

The severity of antilysozyme activity (ALA) and adhesive properties of strains isolated from affected areas of the skin was significantly higher than in cultures isolated from intact skin areas, both qualitatively and quantitatively. The obtained data made it possible to assume a certain complicating role of these factors on the course of AD.
\end{abstract}

Keywords: clinical strains of staphylococci, antilysozyme activity, adhesive properties.

\title{
1. Introduction
}

Microorganisms of the Staphylococcus genus act as the etiological factor of various inflammatory diseases of man, characterized by a variety of course - from the lightest to the heaviest generalized forms $[1,2]$. According to different authors, from the skin of $80-95 \%$ of patients are sown Staphylococcus aureus [3, 4]. The survival of bacteria in a biotope is promoted by the persistent properties of microorganisms. [5]. Long-term preservation of the population of microorganisms in the host organism is facilitated by the mobility of biological properties, considered as a mechanism for the persistence of microbes [6, 7]. It is known that one of the most important factors for any microorganism is its adhesion to competent host cells, which serves as the first step for the development of the infectious process [3, 8]. It ensures the colonization of tissues by both pathogenic and non-pathogenic microorganisms and is a necessary condition for the natural lifestyle of most bacteria. Adhesion is a trigger mechanism for the realization of pathogenic properties of pathogens, which allows microorganisms to be fixed in a certain biotope and reach the required population level. Most researchers believe that microorganisms that possess high adhesiveness become the causative agents of infections [1,8]. Of all the varieties of staphylococcus species, one of the most significant super bacteria is $S$. aureus, which is considered to be a highly-adherent microorganism $[9,10]$. This property is determined by three regulatory genes: the agr gene (accessory gene regulator), expr (exstracellular protein regulator), sar (staphylococcus accessory regulator) [1,11]. Staphylococci show a pronounced adhesive activity to the skin, are capable of intense invasion of tissues, significantly inhibit phagocytosis, are able to persist for a long time inside phagocytes $[6,12]$. The condition for the survival of bacteria in a biotope is the ability to withstand the existing mechanisms of anti-infective resistance of the host organism due to a number of persistent characteristics, which include the property of bacteria specifically to inactivate the lysozyme of the host, which is defined as antilysozyme activity. Lysozyme or $\mathrm{N}$-acetylmuramidase is an enzyme that ruptures the $1-4 \beta$-glycosidic bond between $\mathrm{N}$-acetyl-glucosamine and $\mathrm{N}$-acetylmuramic acid in the peptidoglycan molecule of the bacterial cell wall, resulting in bacterial lysis $[13,14]$. Antilysozyme activity is one of the factors that increase the tolerance of bacteria to the action of serum lysozyme in humans and animals 
[15]. The role of lysozyme in protecting the macroorganism from infection is well known. Some authors believe that antilysozyme activity contributes to the long-term survival of bacteria in the macroorganism [16, 17].

Thus, the detection of high levels of adhesiveness and antilysozyme activity in bacteria can be used in bacteriological laboratories to assess the etiological role of isolated cultures of microorganisms and was chosen by us as an initial stage in the study of the pathogenic characteristics of laboratory strains.

\section{Aim of the research}

Determination of adhesive properties and antilysozyme activity of clinical strains of staphylococci isolated from the skin of patients with allergic dermatosis.

\section{Materials and methods}

The material for the research was laboratory strains of staphylococci, isolated from the lesions and healthy areas of the skin of patients with allergic dermatosis and practically healthy individuals.

Sowing of biological material from lesions on the skin, identification of isolated bacteria was carried out using methods of classical bacteriology. Interpretation of the results was carried out according to international protocols and normative documents of the Ministry of Health of Ukraine [18, 19].

Determination of adhesion-colonization properties of microorganisms was carried out according to the method of V. I. Brilis [20]. As cellular substrate was formalized human erythrocytes 0 (I) $\mathrm{Rh}(+)$. The average index of adhesion (AIA) and the index of adhesion of microorganism (IAM) were determined. AIA - the average number of microbes adhered on one erythrocyte, when counting at least 25 erythrocytes. Adhesiveness was considered zero at an AIA of 0 to 1.0; low - from 1.1 to 2. 0 ; average - from 2.1 to 4.0 and high $->4.0$. IAM is the average number of microorganisms on one erythrocyte participating in an adhesive process. Non-adhesive are microorganisms with IAM $\leq 1.75$; low-adhesive - with IAM from 1.76 to 2.5 ; medium-adhesive - from 2.51 to 3.99 and high-adhesive $\geq 4.0$ bacteria / erythrocyte.

Antilysozyme activity of the isolated microorganisms was determined by the method of detached antagonism by the method of O. V. Bukharin [21]. M. luteus was used as an indicator strain (strain 2665 of the GISK named after L. A. Tarasevich). The activity of the strains was evaluated in $\mu \mathrm{g} / \mathrm{ml}$. The isolated strains were divided into 3 groups: 1 - strains isolated from affected areas of the skin of patients with AD; 2 - strains isolated from intact sections of the skin of patients with $\mathrm{AD} ; 3$ - strains isolated from the skin of healthy individuals.

\section{Results of the research}

As a result of bacteriological studies, comparative data were obtained on the staphylococcal component of the skin microbiocenosis of 50 patients with atopic dermatitis and 20 practically healthy individuals. During the research 140 laboratory strains of staphylococci were isolated: 101 strains from patients with AD and 39 control strains. In Fig. 1 is shown the percentage of the most common types of staphylococci.

To study the pathogenic characteristics of staphylococci strains, the initial stage of the research was the investigation of the adhesive activity of isolated microorganisms. In Fig. 2 is shown the results of the obtained adhesion-colonization indices of $S$. aureus (AIA - the average index of adhesion, IAM - the index of adhesion of microorganisms)

Further, the obtained data were analyzed to determine the percentage distribution of high-, moderate-, low-adhesive isolates. In Fig. 3 is shown the percentage of strains depending on the degree of adhesion.

In Fig. 4 is illustrated the difference in the percentage of strains with ALA isolated from different parts of their vegetation.

Fig. 1. Species composition of skin biotopes 


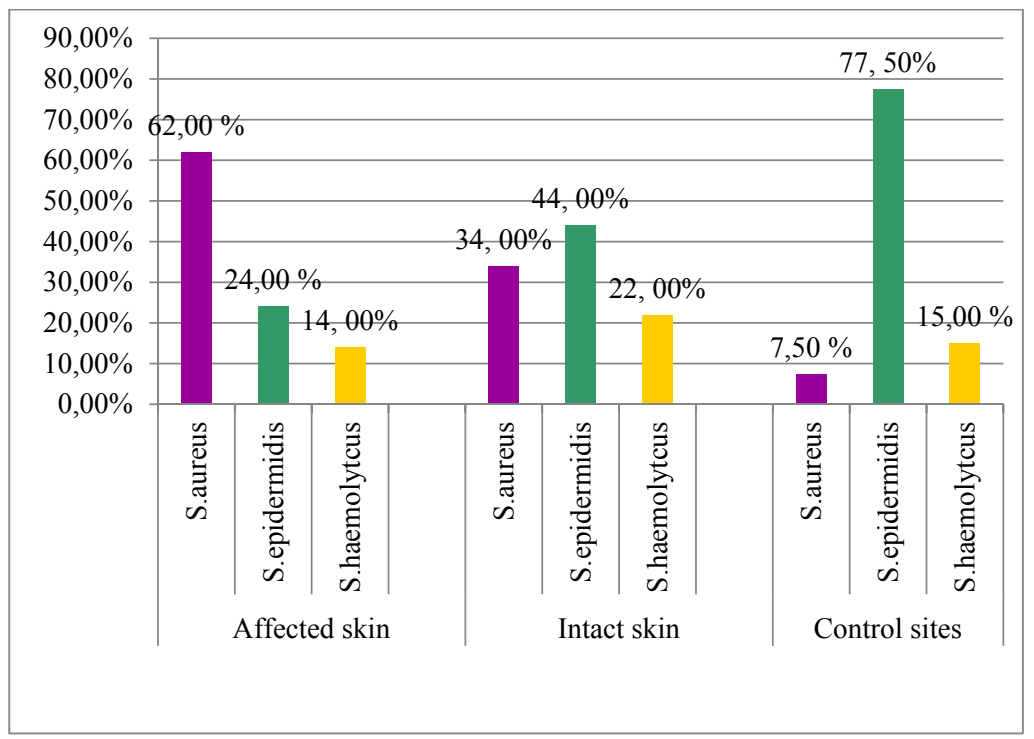

Fig. 2. The results of the adhesion-colonization indices of $S$. aureus $(\mathrm{p}<0.05)$

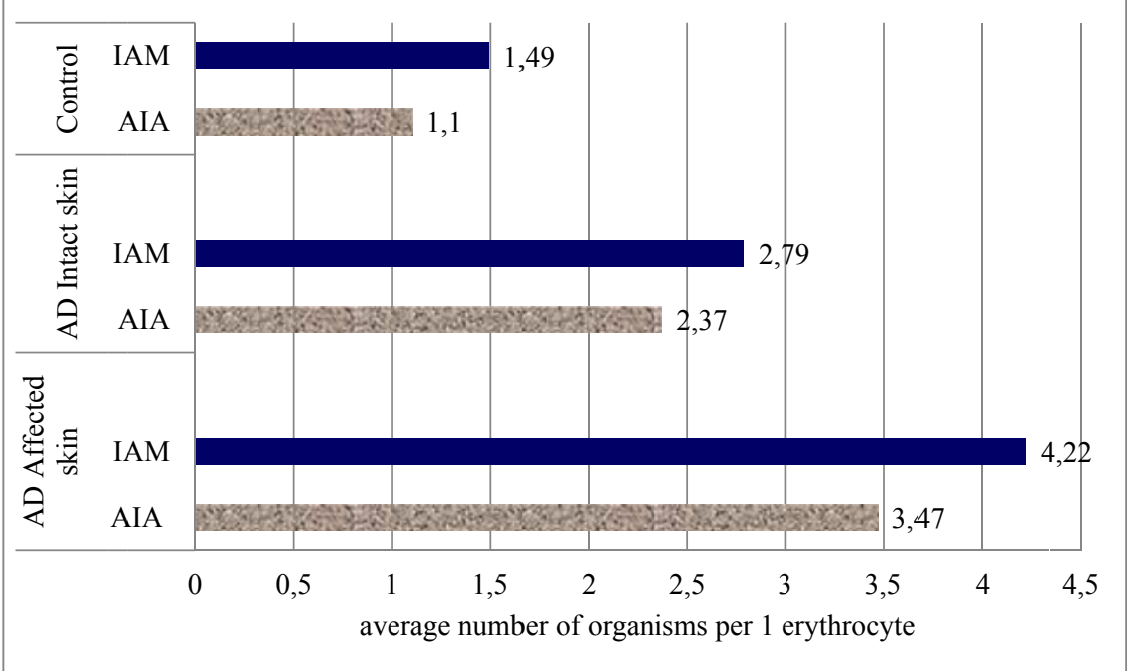

Fig. 3. Distribution of $S$. aureus strains according to the degree of adhesiveness

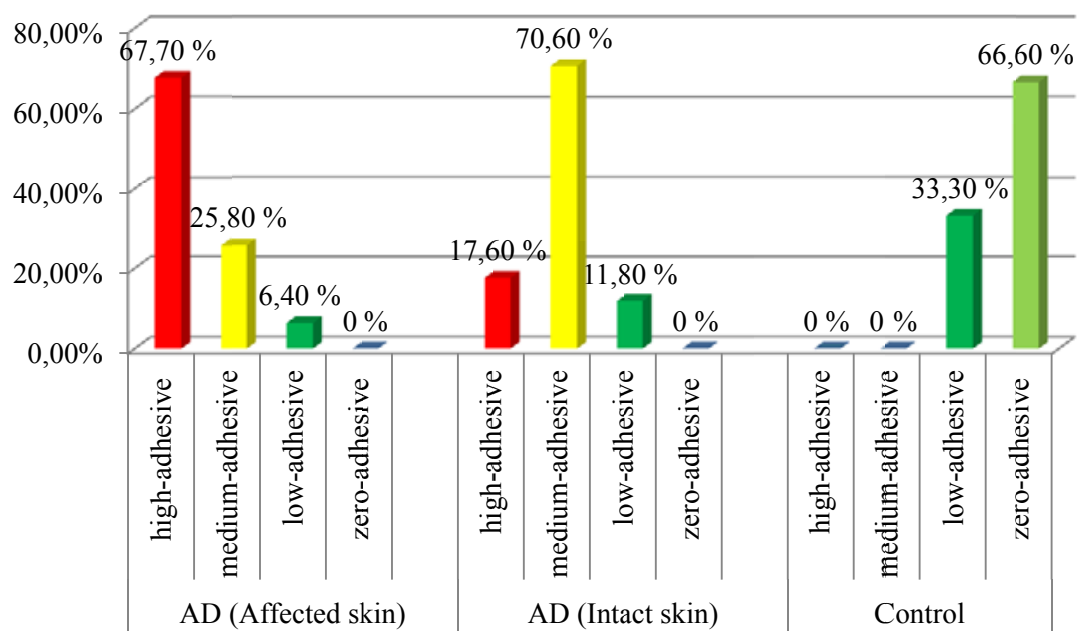

Fig. 4. Frequency of detection of strains of staphylococci with antilysozyme activity 


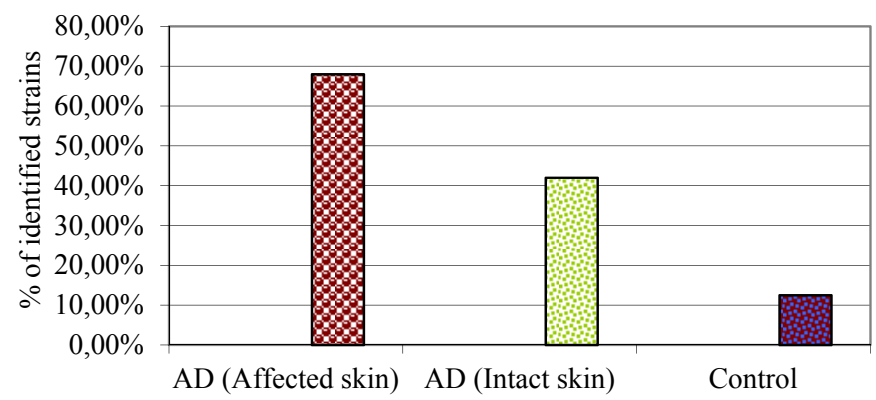

The next step was a comparative analysis to identify this property (ALA) among the dominant species of staphylococci. This group included S. aureus, S. epidermidis and S. haemolyticus. The obtained data are shown in Fig. 5.

Fig. 5. The presence of ALA in strains of staphvlococci of different species on the affected and

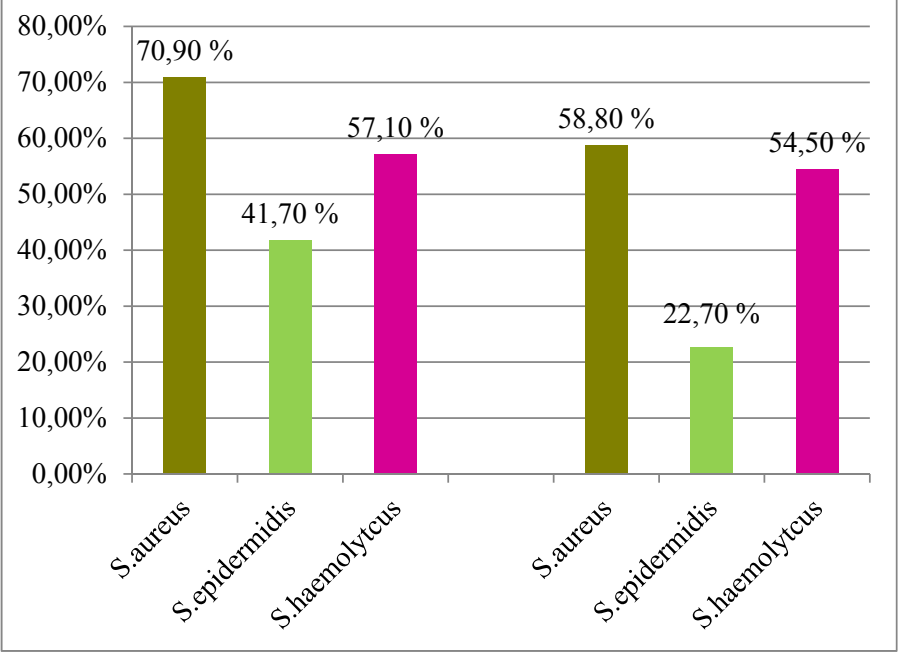

intact sites

Further, a determination of the absolute indices of ALA was made, the values of which are not illustrated by the diagrams, but are given in the discussion.

\section{Discussion}

As a result of bacteriological studies, a picture of the microbial landscape of the skin biome was obtained. The study of the microbial constituents of the biotope showed the dominance of microorganisms of the Staphylococcus genus on the skin of both patients and healthy individuals. The difference was observed in the species composition of staphylococci and the degree of contamination of lesions and normal skin areas. The emergence of non-resident species of staphylococci with a higher pathogenic potential in the affected and intact skin areas was a distinctive feature for most patients. Staphylococcus strains belonging to the species were selected for the research, the percentage of which was highest. They include S. aureus, S. epidermidis and S. haemolyticus, the percentage of which is shown in Fig. 1.

After obtaining strains of staphylococci with stable properties, the process of studying their pathogenic characteristics was launched. The initial stage of the study was the study of the adhesive activity of isolated microorganisms. First of all, our attention was paid to the study of the adhesive activity of the pathogen of the genus $S$.aureus. Figure 2 shows the results of the obtained adhesion-colonization indices of $S$. aureus - AIA and IAM. The diagram in Fig. 2 illustrates that high adhesion-colonization indices were detected in a group of strains isolated from affected areas of the skin of patients with atopic dermatitis: the mean adhesion value of the AIA - $(3.47 \pm 0.21)$ bacteria/ red blood cell and the adhesion index microorganism IAM - $(4.22 \pm 0.32)$ bacteria/erythrocyte, 
which is almost 1.5 times higher than in the group of strains isolated from intact areas of the skin of patients with $\mathrm{AD}$ and 4 times higher than in the control group.

The distribution of $S$. aureus strains according to the degree of adhesiveness presented in Fig. 3 shows that in the first group of strains isolated from the affected skin areas of patients, highly adhesive strains dominated, a lower percentage of trait detection was observed among isolates with a moderate degree of adhesion, and low-adhesive microorganism cultures amounted to less than $10 \%$. Among the strains isolated from the same patients, but from intact skin areas, the picture was somewhat different. The predominance of moderately adhesive strains was noted, while high and low-adhesive strains were found in small amounts. Strains isolated from the skin of practically healthy individuals showed up to a third of low-adhesive, and the others did not demonstrate the presence of the test feature.

As already noted, the development of diseases of microbial etiology largely depends on the persistent properties of microorganisms aimed at inactivating the factors of human natural resistance. Studies of bacterial antilysozyme activity (ALA), which inactivates the lysozyme of the macroorganism, have revealed a wide prevalence of this feature.

In Fig. 4 illustrated the difference in the percentage of strains with ALA isolated from different parts of their vegetation. As a result of our study, it was found that $68.0 \%$ of the strains isolated from affected skin areas of patients with AD had this feature, while among the strains isolated from intact skin areas and from healthy people this indicator was $42.0 \%$ and $12.5 \%$, respectively. Thus, when comparing the number of strains possessing this property, it is noticeable that the presence of antilysozyme activity was a more characteristic feature for staphylococci, the site of vegetation of which was parts of the affected skin.

As can be seen in the diagram in Fig. 5, the number of strains of $S$. aureus and S. epidermidis that possessed this property gradually decreased from $70.9 \%$ to $58.8 \%$ in the series from lesions to intact sites and from $41.7 \%$ to $22.7 \%$, respectively. For $S$. haemolyticus strains, the number of isolates with this feature was not significantly different between the affected and intact skin areas $(57.1 \%$ and $54.5 \%)$. The diagrams do not include data on control strains, since the absolute figures appeared insignificant, and the percentage did not give a proper illustration of the presence of this property. It is understood that, for example, one of the 3 strains of $S$. aureus had one feature, and out of 31 isolates of $S$. epidermidis ALA had been established in 2. For a strain of S. haemolyticus species, isolated in healthy people, this property was not revealed.

In determining the absolute indices of ALA, the following results were obtained: in the areas of the affected skin, the antilysozyme activity of $S$. aureus strains reached $(2.95 \pm 0.2) \mu \mathrm{g} / \mathrm{ml}$, S. haemolyticus $-(2.23 \pm 0.1) \mu \mathrm{g} / \mathrm{ml}$, S. epidermidis $-(1.32 \pm 0.08) \mu \mathrm{g} / \mathrm{ml}$, i. e. the results indicate a higher pathogenic potential of Staphylococcus aureus. The study of intact skin areas showed lower values. But at the same time, it should be emphasized that comparing the results of studying strains with ALA isolated from patients and control areas of the skin of healthy people showed significant differences in antilysozyme activity. First, there were a significantly smaller number of strains with this trait, isolated from the studied topodemes of healthy skin. Thus, out of the $3 \mathrm{~S}$. aureus strains obtained, only one was characterized by the presence of ALA, while its quantitative expression was significantly lower. Among the strains of $S$. haemolyticus this trait is not revealed. Finally, only $6.5 \%$ of strains of $S$. epidermidis had this feature, but again the quantitative indices were minimal. The results of the study of individual factors of persistence of different types of staphylococci emphasize the importance of $S$. aureus from the position of potentiating the complications of the course of the underlying disease.

In a comparative analysis of the obtained data with the results of similar studies, it was found that the adhesion rates of our strains were somewhat lower, and the antilysozyme activity was slightly higher than other authors had. In a percentage ratio, the prevalence indicators obtained were comparable to each other [22].

Thus, complex set of virulent properties of $S$. aureus associated with confronting host defence mechanisms, on the one hand, and high adhesive potential, on the other hand, promote active colonization of both affected and intact skin areas, which provides conditions for prolonged persistence. 


\section{Conclusions}

1. Adhesiveness of strains of $S$. aureus isolated from affected skin is almost 1.5 times higher than in strains with intact skin and 3.5 times higher than in strains from control sites. A greater number of strains with high and moderate adhesion rates were detected on the affected skin $(67.7 \%$ and $25.8 \%)$, if they were absent in the control areas.

2. The severity of antilysozyme activity in strains isolated from affected areas of the skin was significantly higher than in cultures isolated from intact skin areas, both qualitatively and quantitatively. Determination of high and moderate values of antilysozyme activity of strains of $S$. aureus in lesions in comparison with healthy skin allows assuming a certain complicating role of this factor on the course of blood pressure.

\section{References}

[1] Ponomarenko, S. V. (2013). Mikrobiologicheskie aspekty stafilokokkovoy infektsii na sovremennom etape (obzor literatury). Annals of Mechnikov Institute, 3, 13-17. Available at: http://www.imiamn. org.ua/journal/3_2013/PDF/4.pdf

[2] Belousova, T. A., Goryachkina, M. A., Katranova, D. G. (2013). Osobennosti microbiotsenoza kozhi u bolnih allergodermatozami: problema vibora napuzhnoy terapii. Clinicheskaya dermatologiya i venerologiya, 11 (3), 107-112.

[3] Kramar, L. V., Zhadchenko, U. V., Khlynina, U. O., Rodionova, N. V. (2012). Fenotipicheskie harakteristiki populyatsii S. aureus, vydelennyh ot razlichnyh kategoriy nositeley. Fundamentalnye issledovaniya, 4 (2), 295-298.

[4] Zecconi, A., Scali, F. (2013). Staphylococcus aureus virulence factors in evasion from innate immune defenses in human and animal diseases. Immunology Letters, 150 (1-2), 12-22. doi: 10.1016/j.imlet.2013.01.004

[5] Buharin, O. V. (2008). Persistentsiya bakterialnyh patogenov kak fiziologicheskiy fenomen. Vestnik Moskovskogo Universiteta. Seriya 16. Biologiya, 1, 6-13.

[6] Mikhailova, L. V., Kramar, V. O., Savchenko, T. N., Klimova, T. N. (2010). Factory sposobstvuyushchie persistentsii uslovno-patogennyh microorganizmov. Vestnik VolGMU, 4 (36), 76-79.

[7] Grebennikova, V. V., Bakscheeva, S. S., Sergeeva, I. V. (2016). Mehanizmy formirovaniya bakterialnogo persistirovaniya microorganizmov, vydelennyh $u$ detey, prozhivaushchih $v$ raznyh ekologicheskih usloviyah. Sovremennye problemy nauki i obrazovaniya, 6. Available at: https://www.science-education.ru/ $\mathrm{ru} /$ article/view?id $=25667$

[8] Paharik, A. E., Horswill, A. R. (2016). The Staphylococcal biofilm: adhesins, regulation, and host response. Virulence Mechanisms of Bacterial Pathogens, 529-566. doi: 10.1128/microbiolspec.vmbf0022-2015

[9] Suharyev, A. V., Gutka, V. O., Patrushev, A. V., Bondar, O. I., Nazarov, R. N. (2012). Kombinirovannaya naruzhnaya terapiya atopicheskogo dermatita, oslozhnyennogo vtorichnoy infektsiey. Vestnik dermatologii i venerologii, 5, 113-118.

[10] Popov, I. V. (2014). Osobennosti microbiotsenoza kozhi pri atopicheskom dermatite. Vestnik poslediplomnogo meditsinskogo obrazovaniya, 2, 58-62.

[11] Arya, R., Princy, S. A. (2015). Exploration of Modulated Genetic Circuits Governing Virulence Determinants in Staphylococcus aureus. Indian Journal of Microbiology, 56 (1), 19-27. doi: 10.1007/s12088$015-0555-3$

[12] Batyrshina, S. V., Chaertdinova, L. A., Chalilova, R. G. et. al. (2013). Microbiotsenoz kozhi u bolnyh atopicheskim dermatitom i ego korrektsiya. Prakticheskaya meditsina, 1-4 (73), 33-37.

[13] Gayrabekov, P. H., Gayrabekova, P. H., Gubhanova, S. A., Turlova, F. S., Umieva, Z. E. (2016). Antilizotsimnaya aktivnost nekotoryh enterobakteriy. Mezhdunarodniy zhurnal prikladnyh i fundamentalnyh issledovaniy, 7 (1), 63-64.

[14] Shimada, T., Park, B. G., Wolf, A. J., Brikos, C., Goodridge, H. S., Becker, C. A. et. al. (2010). Staphylococcus aureus Evades Lysozyme-Based Peptidoglycan Digestion that Links Phagocytosis, Inflammasome Activation, and IL-1 $\beta$ Secretion. Cell Host \& Microbe, 7 (1), 38-49. doi: 10.1016/ j.chom.2009.12.008 
[15] Findik, B. T., Say, R., Unluer, O. B., Demirel, R., Ersoz, A. (2016). Lysozyme Cross-Linked Antibodious Destroyers Against Staphylococcus aureus. Hacettepe Journal of Biology and Chemistry, 44 (4), 477-486.

[16] Bera, A., Herbert, S., Jakob, A., Vollmer, W., Gotz, F. (2005). Why are pathogenic staphylococci so lysozyme resistant? The peptidoglycan O-acetyltransferase OatA is the major determinant for lysozyme resistance of Staphylococcus aureus. Molecular Microbiology, 55 (3), 778-787. doi: 10.1111/j.13652958.2004.04446.x

[17] Kong, C., Chee, C.-F., Richter, K., Thomas, N., Abd. Rahman, N., Nathan, S. (2018). Suppression of Staphylococcus aureus biofilm formation and virulence by a benzimidazole derivative, UM-C162. Scientific Reports, 8 (1). doi: 10.1038/s41598-018-21141-2

[18] Ob unifikatsii mikrobiologicheskih (bakteriologicheskih) metodov issledovaniya, primenyaemih v kliniko-diagnosticheskih laboratoriyah lechebno-profilakticheskih uchrezhdeniy (1985). Ministerstvo zdravookhraneniya SSSR, No. 535. Available at: http://www.alppp.ru/law/zdravoohranenie--fizicheskaja-kultura-i-sport--turizm/zdravoohranenie/64/prikaz-minzdrava-sssr-ot-22-04-1985--535.html

[19] Baron, E. J., Miller, J. M., Weinstein, M. P., Richter, S. S., Gilligan, P. H., Thomson, R. B. et. al. (2013). A Guide to Utilization of the Microbiology Laboratory for Diagnosis of Infectious Diseases: 2013 Recommendations by the Infectious Diseases Society of America (IDSA) and the American Society for Microbiology (ASM)a. Clinical Infectious Diseases, 57 (4), 22-121. doi: 10.1093/cid/cit278

[20] Brilis, V. I., Brilene, T. A., Lentsner, Kh. P., Lentsner, A. A. (1986). Metodika izucheniya adgezivnogo protsessa microorganizmov. Laboratornoe delo, 4, 210-212.

[21] Buharin, O. V., Valyshev, A. V., Elagina, E. E. (2000). Antilizotsimnaya aktivnost anaerobnyh bakteriy fekalnoy mikroflory cheloveka. Zhurnal microbiologii, epidemiologii i immunologii, 5, $20-22$.

[22] Falova, O. E. (2011). Vzaimosvyaz i stepen vurazhennosti adgezivnoy sposobnosti i antilizotsimnoy aktivnosti stafilikokkov, vydelennyh s kozhi ludey, stradaushchih hronicheskimi dermatozami. Vestnik Tomskogo Gosudarstvennogo Universiteta, 349, 188-189.

\title{
CLINICAL-LABORATORY MARKERS OF FIBRILOGENESIS DISORDERS IN THE SEVERITY OF PYELONEPHRITIS IN CHILDREN
}

\author{
Natalia Lukyanenko \\ Department of Clinical Genetics \\ Institute of hereditary pathology of the National Academy of Medical Sciences of Ukraine \\ 31 M. Lysenko str., Lviv, Ukraine, 79000 \\ Department of Propaedeutics of Pediatrics and Medical Genetics \\ Lviv National Medical University, Ukraine, \\ 69 Pekarska str., Lviv, Ukraine, 79010 \\ nslukyanenko@gmail.com \\ Mariana Iskiv \\ Department of Epidemiology congenital and hereditary pathology \\ Institute of hereditary pathology of the National Academy of Medical Sciences of Ukraine \\ 31 M. Lysenko str., Lviv, Ukraine, 79000 \\ iskivmarjana20@gmail.com
}

\footnotetext{
Abstract

Aim of the research: to establish the role of undifferentiated connective tissue dysplasia, as a manifestation of violation of fibrillogenesis, in the severity of the course of pyelonephritis in children.

148 children with pyelonephritis from 3 to 18 years were examined. As a result of catamnestic surveillance, they were divided into 2 groups: I- 92 persons, children with chronic pyelonephritis in which were diagnosed 3 or more episodes of relapse of pyelone-
} 